\title{
Drug firms vow to tone down consumer advertisements
}

In an attempt to deflect Congressional regulation, the pharmaceutical industry has announced voluntary measures that would temper the tone of consumer-directed drug advertisements. The move comes amidst growing public distrust of the ads, and tighter regulatory scrutiny.

The US Food and Drug Administration (FDA) has recently doubled the number of warning letters it sends to pharmaceutical companies about false or misleading ads. The agency also announced in August that it intends to conduct a comprehensive review of its advertising regulations for the first time in a decade.

The guidelines, detailed 2 August by the Pharmaceutical Research and Manufacturers of America (PhRMA), ask the group's member companies to more accurately convey drug benefits and risks in their direct-to-consumer ads.

Two companies also made independent decisions to rein in their drug ads. Bristol-Myers Squibb on 13 June announced that it would not launch consumer ads for one year after a medicine is introduced, allowing the company time to first educate physicians. Pfizer said on 11 August that it would improve its ads to better communicate risks and reinforce the doctor-patient relationship. It also promised to invest as much in a campaign addressing important public health issues as it typically spends on ads for a branded drug.

The industry is responding to a backlash

against a flood of print and broadcast advertising prompted by a loosening of FDA regulations in 1997. Spending on ads grew from $\$ 965$ million that year to $\$ 4.1$ billion in 2004, according to IMS Health, a market research firm.

As the number of ads has grown, so has the public's distrust of them. According to a February poll by the Kaiser Family Foundation, $18 \%$ of respondents said they could trust ads "most of the time," compared with 33\% in 1997.

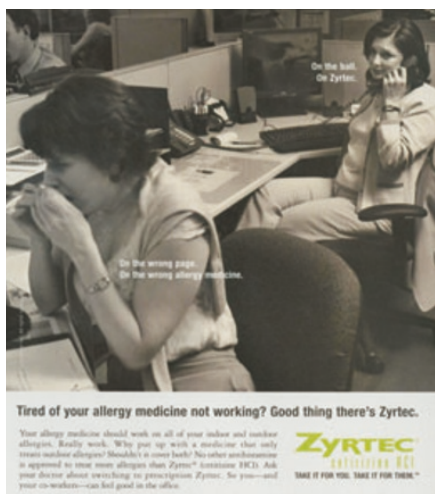

After being warned about ads for Zyrtec, Pfizer is changing the way it promotes its drugs.
In an effort to improve the ads' public image, the PhRMA guidelines call on manufacturers to cease 'reminder' ads-which name drugs but not their uses or risks - and to target ads to appropriate audiences, for instance by not airing television ads for erectile dysfunction drugs until children are asleep. They also suggest that companies should educate doctors about new drugs before launching consumer ads.

Critics assailed these steps as inadequate and insisted that more government power is needed to regulate the ads. "As long as there is no one out there cracking the whip on drug companies, you will have these dangerous, misleading ads going from 24 in all of 2004.

out and people taking drugs that are more dangerous and less effective than they seem to be," says Sidney Wolfe of Public Citizen, a liberal watchdog group.

Wolfe says the FDA should be given the power to impose large fines on companies that make false or misleading commercials, rather than the letters it now sends, demanding $\stackrel{4}{5}$ that they immediately pull offending ads. As of 31 July, the agency had sent 27 warning letters this year, up

But Jack Calfee, a resident scholar at the conservative American Enterprise Institute in Washington, says the ads provide patients with important information that neither the government nor physicians are equipped to disseminate.

Republican Senator Charles Grassley, who chairs the Senate Finance Committee, has introduced legislation that would require ads for new drugs to be vetted by the FDA during the first two years they are on the market. By contrast, Grassley noted, the PhRMA guidelines provide "not a single guarantee for consumers." Meredith Wadman, Washington, DC

\section{Loss of grants review board leaves Australian scientists wary}

Grants given by Australia's primary funding

agency for basic research will go through one less step on their way to approval, a move scientists say will leave the process vulnerable to political whim. The nation's medical and health funding agency is also to be restructured, but biomedical researchers are in the dark as to the possible outcome.

The Australian Research Council administers about US\$420 million in competitive grants each year. Following peer review of grant applications, recommendations are passed along to the board-made up of leading community, industry and academic representativesbefore being sent to the agency's chief executive, and then to the federal science and education minister for final approval.

But on 15 July, the government announced plans to dissolve the board, effective early in 2006. The agency's chief executive, currently Peter Høj, will report solely to the minister.

The decision follows last year's governmentcommissioned report, which examined the way various agencies are run, and recommended that the agencies be governed either by a chief executive or a board-but not both.

The government says eliminating board review will expedite the grant-approval process. But John Mullarvey, chief of the Australian Vice-Chancellors' Committee, says it will compromise the integrity of the process. "There will be less transparency in the decision-making process," he says.

Snow Barlow, president of the Federation of Australian Scientific and Technological Societies, based in Canberra, adds that the board functions as a critical buffer to political interference. "There is a dangerous potential for loss of independence," Barlow says.

The National Health and Medical Research Council (NHMRC), the nation's major funding agency for biomedical research, is also up for an overhaul. But the government is guarded about the details. "The minister is still considering," says a ministry spokesperson.

In December 2004, a governmentcommissioned review of investment into medical research called for the creation of an NHMRC board to streamline the agency's administration, and recommended a substantial increase in the agency's budget.

Commissioned in October 2003, that report was not released until December 2005. Researchers were frustrated by the report's late release, amidst speculation that the government wanted to deflect attention from a recommendation to increase funding for biomedical research.

Researchers say the NHMRC should not be forced into one of the two models proposed by the government report, given the agency's diverse roles in funding, policy making and regulation of research areas, such as reproductive technology. "There is a sound argument given the range of roles of the NHMRC for having a tailored model that recognizes these specific functions," says Christine Bennett, chief executive of Research Australia, an independent organization that promotes investment in medical research.

Carina Dennis, Sydney 